\title{
The Short Form Health Survey (SF-36): translation and validation study in Afghanistan
}

Nasar Ahmad Shayan ${ }^{1, a}$ Umut Ece Arslan,, a Abdul Malik Hooshmand, ${ }^{3}$ Mohammad Zobair Arshad ${ }^{4}$ and Hilal Ozcebe ${ }^{5}$

${ }^{1}$ Department of Public Health, Faculty of Medicine, University of Herat, Herat, Afghanistan. ${ }^{2}$ Institute of Public Health, University of Hacettepe, Ankara, Turkey. ${ }^{3}$ Department of Dermatology, Faculty of Medicine, University of Herat, Herat, Afghanistan. ${ }^{4}$ Afghanistan Private Hospital Association, Herat, Afghanistan. ${ }^{5}$ Department of Public Health, Faculty of Medicine, University of Hacettepe, Ankara (Correspondence to: H. Ozcebe: hilalozcebe@ gmail.com). a Both authors contributed equally and shared first authorship

\begin{abstract}
Background: Quality of life is defined as the subjective perception of one's own well-being within a sociocultural context. SF-36 is commonly used to check the health status of the general population in many countries.

Aims: To validate the Persian (Dari) version of the Short Form Health Survey (SF-36) in Herat.

Methods: The Persian (Dari) version of SF-36 was culturally adapted. A total of 1259 healthy individuals aged $\geq 18$ years participated in the study between November 2016 and April 2017. Construct validity of SF-36 was evaluated through exploratory factor analysis. The extraction was performed by principal component analysis from the polychoric correlation matrix estimated by a 2-step method with varimax rotation. Internal consistency and test-retest reliability were assessed by Cronbach's $\alpha$ SPSS version 23.0 and R version 3.1.3 were used in the analysis.

Results: The last version of SF-36 including 27 items in 8 factors explained $86.48 \%$ of the variance. The Kaiser-MeyerOlkin value was 0.391 and Bartlett's test showed statistical significance $(P<0.001)$. Confirmatory factor analysis revealed that the final model demonstrated good fit statistics $(P<0.001)$, root mean square error of approximation=0.056, goodness-of-fit index $=0.963$, and adjusted goodness-of-fit index=0.953). Cronbach's $\alpha$ for the 8 subscales was $0.753-0.933$. All subscales of SF-36 had good internal consistency reliability and good test-retest reliability.

Conclusions: We showed that our Dari version of SF-36 is suitable to evaluate quality of life in adults in Herat City. This scale will be useful for health researchers in the future.

Keywords: Afghanistan, Dari, quality of life, SF-36, validity

Citation: Shayan NA; Arslan UE; Hooshmand AM; Arshad MZ; Ozcebe H. The Short Form Health Survey (SF-36): translation and validation study in Afghanistan. East Mediterr Health J. 2020;26(8):899-908. https://doi.org/10.26719/emhj.20.064

Received: 23/07/18; accepted: 27/03/19

Copyright ( ) World Health Organization (WHO) 2020. Open Access. Some rights reserved. This work is available under the CC BY-NC-SA 3.0 IGO

license (https://creativecommons.org/licenses/by-nc-sa/3.o/igo)
\end{abstract}

\section{Introduction}

Quality of life (QOL) is either defined as the subjective perception of one's own well-being within a sociocultural context, or as the satisfaction of a person's desires and achieving an ideal level of well-being. Health-related QOL (HRQOL) refers to functioning and wellbeing in physical, mental and social dimensions of life (1-3).

Measuring the health status of individuals or a population is an important first step in the assessment of healthcare needs and evaluation of the impact of health interventions. The indicators of QOL are used to measure the effects of symptoms and treatment on people's health status (4-8). Measuring QOL in the community is also helpful in health planning (9). Reliable populationwide statistics on health status are scarce, especially in developing countries such as Afghanistan.

The 36-item Short Form Health Survey (SF-36) is a renowned generic health-related QOL questionnaire that was developed by Boston Health Research Institute. The SF-36 instrument provides a concise method that is mainly used to check the health status of members of the general population as well as that of patients aged $\geq 14$ years (1). As it is easy to administer, it has become one of the most widely used QOL evaluation tools in the world $(6,8-12)$. SF-36 is also widely used among different age groups in Middle Eastern countries (13). Psychometric analyses of the translated versions provided evidence that SF-36 is a reliable and valid measure in different populations (14-19), and a few studies have translated and culturally adapted SF-36 into different Asian languages (20-23).

There is increasing demand by healthcare professionals and researchers to have and include an authenticated QOL questionnaire in their research or clinical investigations in Afghanistan. This study reported the development and validation of a Persian (Dari)/Afghan version of SF-36 and the results of its testing in the general population in Herat; a province in Southwest Afghanistan where most of the population communicates in Persian.

\section{Methods}

\section{SF-36}

SF-36 measures 8 health-related subscales: Physical functioning ( $\mathrm{PF}, 10$ items); role limitation due to physical 
health (RLPH, 4 items); bodily pain (BP, 2 items); general health perception ( $\mathrm{GH}, 5$ items); vitality (VT, 4 items); social functioning (SF, 2 items); role limitation due to emotional problems (RLEP, 3 items); and perceived mental health ( $\mathrm{MH}, 5$ items). A single item that provides an indication of perceived change in general health status over a 1-year period (health transition) is also included. SF-36 is also evaluated by physical health component (PHC) and mental health component (MHC). While PF, RLPH, BP and $\mathrm{GH}$ are considered under the dimension of PHC, VT, SF, RLEP and MH are under the dimension of MHC (1).

\section{Translation of SF-36}

Translation of the Persian (Dari) version of SF-36 involved 3 steps. The standard forward-backward translation method was followed to translate the SF-36 questionnaire. The SF-36 questionnaire was translated into Persian (Dari) by 2 independent health professionals. Persian literature lecturers reviewed the translated questionnaire to assess Afghan culture and language appropriateness. This questionnaire was back-translated into English by 2 professional translators to check for differences between the Persian and original English versions. A few changes were made and the provisional version of the questionnaire was provided on the basis of the results of the cultural adaptation. There were no difficulties with translation of questions and response categories. Changes were only made in a few items regarding activities, namely: playing golf had been changed to light sporting activities such as snooker and billiards; and measurements like mile was changed to kilometre, and block to approximately 1 or a few hundred meters, which are more familiar in Persian language and Afghan society. The provisional forward-translated questionnaire was pilot tested and administered to 50 healthy individuals, and almost all stated that did not have any difficulties completing the questionnaire. The results of pilot testing were analysed by the research team and after review, only a few changes were made, and the final version was used in this study.

\section{Data collection}

This study was conducted in Herat City, Afghanistan from November 2016 to April 2017. The Persian version of SF-36 was administered to a random sample of healthy individuals aged $\geq 18$ years living in Herat City from November 2016 to April 2017. Our final questionnaire contained 2 main parts: the first included questions about sociodemographic characteristics, economic status, and cultural and daily activities; and the second had only questions in SF-36. Since SF-36 had 36 questions, we considered a minimum 15 individuals were needed for each question, so our minimum sample size was 540 for the test and $\sim 200$ for the retest. The inclusion criteria were: age $\geq 18$ years; residents of Herat City; knowledge of Persian (Dari) language; and no psychological disorder that could affect the answers.

The field coordinator and 15 interviewers were trained in the aim of the research, the questionnaire and data collection methods by an Afghan researcher. Herat City has 15 districts, and 1 hospital in each district was selected for the study. The selected hospitals were the most used by people in the district. The interviews were done face to face with the patients and their relatives at 15 general hospitals in 15 different districts of Herat City.

In order to evaluate the validity of SF-36, which is a Likert-type scale, we needed 15 participants for each question with a target total of 540 participants who attended the selected district hospitals. Data collection was continued until at least 90 people were reached in each age group from November 2016 to April 2017. There were 1259 interviewees ( $54 \%$ female and $46 \%$ male) and 259 (52.1\% male and $47.9 \%$ female) were contacted for the retest study.

\section{Statistical analysis}

SPSS version 23.0 (SPSS, Chicago, IL, USA) was used to calculate the descriptive analyses such as frequencies, percentage distributions, means, and standard deviation. $P<0.05$ was considered statistical significance.

Exploratory factor analysis was used to assess the construct validity by using free software $\mathrm{R}$ version 3.1.3 (packages: psych, polycor, GPArotation, nFactors, corpcor, ICS, R.utils) and SPSS. Polychoric correlation coefficients were used for explanatory factor analysis because SF-36 is a Likert-type scale and the individual items are not interval scaled (26).

Principal component analysis (PCA) from the polychoric correlation matrix estimated by a 2-step method with a varimax rotation was applied for data extraction. It was accepted that factor loading $>0.32$ was considered statistically significant (1). Six items were dropped from SF-36 because factor loading of these items was < 0.32. After deletion of items 1, 2, 8, 12, 26, 29, 30, 31 and 35, the data were reanalysed. The Kaiser-MeyerOlkin (KMO) statistic and Bartlett's test were carried out to check for sampling suitability. Confirmatory factor analysis (CFA) was used to determine the goodness of fit of the 8-subscale model after explanatory factor analysis. The following parameters were used to evaluate model fit: $\mathrm{c}^{2}$ to $\mathrm{df}$ ratio (CMIN/df), root mean square error of approximation (RMSEA), goodness-of-fit index (GFI), adjusted GFI (AGFI). The following criteria were used to assess model fit: CMIN/df < 5, RMSEA < 0.08, GFI > 0.90 and AGFI >0.90 (27,28).

PCA was used to reduce the two dimensions of the scale ( $\mathrm{PHC}$ and $\mathrm{MHC}$ ). The summary scores of PHC and MCH were obtained by PCA. Spearman's rho correlation coefficient was used for correlation between the 8 subscales (PF, RLPH, BP, GH, VT, SF, RLEP and $\mathrm{MH}$ ) and the 2 rotated components (PHC and $\mathrm{MCH})$. Reliability was estimated using the test-retest correlation coefficient and the internal consistency (Cronbach's $\alpha$ ). To assess test-retest reliability, 259 people completed the questionnaire twice at 3-week intervals. Spearman's rho correlation coefficient (> 0.6 as reliable) was used for the test-retest reliability (23). Internal consistency was calculated by using 
Cronbach's $\alpha$, which was considered acceptable at $\geq 0.70$ $(27,28)$. Spearman's rho correlation coefficient was also used to evaluate the relationship between 2 subscales of SF-36.

\section{Ethical approval}

All procedures involving human participants were performed in accordance with the ethical standards of the institutional and/or national research committee and with the 1964 Helsinki Declaration and its later amendments, or comparable ethical standards. Permission from the RAND Corporation was obtained via email for using SF-36 for this research. We obtained the approval of the Ethics Committee and Research and Development Committee of Herat University Faculty of Medicine. Informed consent was obtained from all individual participants included in the study.

\section{Results}

In this study $56 \%$ of participants were from urban area, $62.4 \%$ of the participants were Tajik, $46 \%$ of the participants were male, $65.5 \%$ were married, and $39.6 \%$ were illiterate (Table 1). More than half of the participants (59.2\%) did not have any income and $23.6 \%$ of them received a regular income under US\$100. Almost $80 \%$ of participants were probably living under or just above the poverty line.

Factor analysis with the polychoric correlation and varimax rotation was performed to construct 8 subscales (Table 2). Items 1, 2, 26, 29, 30, 31 and 35 (in MH, GH and VT) were loaded on the different subscales. Two items (8 and 12) had low standardized estimates. Therefore, the 9 items were dropped from the original scale. After that, explanatory and confirmatory factor analysis were reanalysed with the remaining 27 items. Total 8 subscales were obtained according to explanatory factor analysis factors and these subscales explained $86.48 \%$ of the variance. KMO value was 0.391 and Bartlett test was statistically significant $(P<0.001)$. The factor structure of the final model obtained from explanatory factor analysis ( 8 subdimension model with 27 items) was tested by CFA. The CFA revealed that the final model demonstrated good fit statistics $\left(c^{2} / d f=4.96, P<0.001\right.$, RMSEA $=0.056$, GFI $=$ 0.963 , AGFI $=0.953$ ) (Figure 1).

Reliability of the scale was evaluated using the test-retest and internal consistency reliability methods (Table 3). Test-retest reliability coefficients ranged from 0.682 to 0.905 . All subscales of SF-36 had good internal consistency and test-retest reliability. There were positive correlation coefficients between each of the 8 subscales of the SF-36 $(P<0.01)$.

Table 4 shows the PCA with varimax rotation, correlation between the 8 scales and the 2 rotated components. KMO was 0.88 and Bartlett's spherical check was $\chi^{2}=6494.45$ and $p<0.001$. Taken together, these results indicated that the study samples were suitable for factor analysis. The analysis identified 2 principal components (PCS and MCS) that could be used

\begin{tabular}{|c|c|c|}
\hline & Percentage & Frequency \\
\hline \multicolumn{3}{|l|}{ Age group, years } \\
\hline $18-29$ & 318 & 25.3 \\
\hline $30-39$ & 249 & 19.8 \\
\hline $40-49$ & 253 & 20.1 \\
\hline $50-59$ & 179 & 14.2 \\
\hline $60-69$ & 170 & 13.5 \\
\hline$\geq 70$ & 90 & 7.1 \\
\hline \multicolumn{3}{|l|}{ Sex } \\
\hline Male & 579 & 46.0 \\
\hline Female & 680 & 54.0 \\
\hline \multicolumn{3}{|l|}{ Nationality } \\
\hline Tajik & 785 & 62.4 \\
\hline Poshton & 317 & 25.2 \\
\hline Other(Ozbik, Hazara) & 157 & 12.4 \\
\hline \multicolumn{3}{|l|}{ Marital status } \\
\hline Married & 825 & 65.5 \\
\hline Single & 316 & 25.1 \\
\hline Widowed & 116 & 9.2 \\
\hline Unknown & 2 & 0.2 \\
\hline \multicolumn{3}{|l|}{ Education status } \\
\hline Illiterate & 499 & 39.6 \\
\hline Can read and write & 197 & 15.6 \\
\hline Primary school & 105 & 8.3 \\
\hline Secondary school & 118 & 9.4 \\
\hline High school & 224 & 17.8 \\
\hline University & 115 & 9.1 \\
\hline Unknown & 1 & 0.1 \\
\hline \multicolumn{3}{|l|}{ Economic status, US\$ } \\
\hline No income & 745 & 59.2 \\
\hline$<100$ & 297 & 23.6 \\
\hline $100-200$ & 165 & 13.1 \\
\hline $200-300$ & 33 & 2.6 \\
\hline $300-400$ & 12 & 1.0 \\
\hline$>400$ & 6 & 0.5 \\
\hline Total & 1259 & 100.0 \\
\hline
\end{tabular}

to explain $70.95 \%$ of the total variance. However, the correlations did not exactly confirm the hypothesized association between the 8 scales with PCS and MCS scores obtained from the first and second components. The VT and GH were strongly correlated with PCS. MH moderately correlated with PCS. The RLEP and RLPH scales were found to have a higher correlation with the MCS than PCS.

\section{Discussion}

Our findings suggest that the SF-36 has acceptable reliability, test-retest correlations and factor validity (polychoric correlation). The aim of this research was to study 
Table 2 Rotated loading matrix: polychoric correlation, principle component extraction, varimax rotation after dropping items 1 , $2,8,12,26,29,30,31$ and 35

\begin{tabular}{|c|c|c|c|c|c|c|c|c|}
\hline \multicolumn{9}{|c|}{ Sorted rotated factor loadings } \\
\hline & $\mathbf{P C 1}$ & $\mathrm{PC}_{2}$ & $\mathrm{PC}_{3}$ & $\mathrm{PC}_{4}$ & PC5 & PC6 & PC7 & PC8 \\
\hline \multicolumn{9}{|c|}{ Physical functioning (PF) } \\
\hline (SF-10) Walking medium & 0.847 & 0.148 & 0.211 & -0.145 & 0.178 & 0.211 & 0.024 & 0.077 \\
\hline (SF- 4) Vigorous activity & 0.844 & 0.140 & 0.144 & -0.217 & 0.229 & 0.146 & -0.169 & 0.101 \\
\hline (SF-5) Lifting or carrying & 0.835 & 0.149 & 0.124 & -0.269 & 0.136 & 0.179 & -0.006 & 0.171 \\
\hline (SF-9) Walking short & 0.829 & 0.127 & 0.205 & -0.115 & 0.269 & 0.165 & -0.178 & 0.126 \\
\hline (SF-3) Moderate activity & 0.801 & 0.104 & 0.151 & -0.105 & 0.302 & 0.135 & -0.323 & 0.119 \\
\hline (SF-11) Walk along distance & 0.785 & 0.167 & 0.171 & -0.291 & 0.131 & 0.236 & 0.240 & 0.033 \\
\hline (SF-6) Climb flight stairs & 0.783 & 0.130 & 0.089 & -0.328 & 0.010 & 0.269 & 0.100 & 0.183 \\
\hline (SF-7) Climb several flights & 0.774 & 0.159 & 0.145 & -0.312 & 0.029 & 0.247 & 0.288 & 0.145 \\
\hline \multicolumn{9}{|c|}{ Role limitation due to emotional problems (RLEP) } \\
\hline (SF-18) Less done like & 0.168 & 0.840 & 0.219 & -0.264 & 0.071 & 0.237 & -0.139 & 0.176 \\
\hline (SF-19) Not carefully & 0.209 & 0.817 & 0.158 & -0.081 & 0.254 & 0.286 & 0.257 & 0.028 \\
\hline (SF-17) Cut down work & 0.227 & 0.802 & 0.258 & -0.293 & 0.028 & 0.262 & -0.112 & 0.064 \\
\hline \multicolumn{9}{|l|}{ Mental health (MH) } \\
\hline (SF-28) Down hearted & 0.164 & 0.124 & 0.786 & -0.119 & 0.127 & 0.145 & 0.016 & 0.053 \\
\hline (SF-25) Unhappy & 0.220 & 0.148 & 0.762 & -0.157 & 0.144 & 0.100 & 0.119 & 0.218 \\
\hline (SF-24) Nervous & 0.167 & 0.234 & 0.711 & -0.248 & 0.172 & 0.011 & -0.173 & 0.055 \\
\hline \multicolumn{9}{|c|}{ Social functioning (SF) } \\
\hline (SF 20) Interfere social & 0.281 & 0.221 & 0.200 & -0.761 & 0.232 & 0.183 & 0.014 & 0.052 \\
\hline (SF 32) Time limit & 0.188 & 0.216 & 0.178 & -0.703 & 0.222 & 0.077 & -0.058 & 0.216 \\
\hline \multicolumn{9}{|c|}{ Bodily pain (BP) } \\
\hline (SF-22) Interfere & 0.330 & 0.126 & 0.166 & -0.793 & 0.178 & 0.230 & 0.048 & 0.045 \\
\hline (SF-21) Body pain & 0.350 & 0.149 & 0.181 & -0.742 & 0.245 & 0.266 & -0.051 & 0.094 \\
\hline \multicolumn{9}{|c|}{ General health (GH) } \\
\hline (SF-36) Excellent health & 0.343 & 0.123 & 0.261 & -0.325 & 0.711 & 0.168 & -0.047 & 0.123 \\
\hline (SF-34) Healthy as others & 0.329 & 0.141 & 0.242 & -0.314 & 0.688 & 0.179 & -0.076 & 0.255 \\
\hline (SF-33) Get sick easier & 0.230 & 0.128 & 0.197 & -0.382 & 0.662 & 0.230 & 0.098 & 0.164 \\
\hline \multicolumn{9}{|c|}{ Role limitation due to physical health (RLPH) } \\
\hline (SF-15) Limited in activity & 0.244 & 0.213 & 0.098 & -0.148 & 0.218 & 0.815 & 0.167 & 0.084 \\
\hline (SF-16) Difficulty performing & 0.375 & 0.255 & 0.100 & -0.172 & 0.210 & 0.776 & 0.082 & 0.035 \\
\hline (SF-14) Accomplished less & 0.314 & 0.316 & 0.112 & -0.301 & 0.089 & 0.689 & -0.347 & 0.197 \\
\hline (SF-13) Cut down on time & 0.356 & 0.299 & 0.168 & -0.386 & 0.037 & 0.676 & -0.263 & 0.107 \\
\hline \multicolumn{9}{|c|}{ Vitality (VT) } \\
\hline (SF-23) Full of life & 0.355 & 0.285 & 0.369 & -0.260 & 0.250 & 0.127 & -0.065 & 0.541 \\
\hline (SF-27) Loss of energy & 0.352 & 0.107 & 0.222 & -0.179 & 0.297 & 0.169 & 0.007 & 0.753 \\
\hline
\end{tabular}

the validity and reliability of the SF-36 Persian-Dari version in Herat City, Afghanistan. This was the first study to assess the SF-36 in an Afghani sample.

Regarding validity, polychoric correlation and varimax rotation were performed to construct 8 subscales. All items in the PF, RLPH, SF, RLEP and BP were loaded on their own subscales. The several items in the $\mathrm{MH}, \mathrm{GH}$ and VT subscales were loaded on the different subscales. The items that measure people's feelings and energy can vary by understanding of social and psychological health in the different cultural communities. Two items in the PF dimension, bending/kneeling and bathing/dressing, were dropped because of their low value of standardized estimates in CFA. The last version of SF 36 which had 27 items was analysed again for explanatory factor analysis. The reason for deleting the items was cultural differences, as in other studies $(16,18,20,22,23)$.

Regarding the internal consistency and test-retest results, Cronbach's $\alpha$ in our study was 0.753-0.933, which is higher than 0.70 as an admitted level for internal consistency, and test-retest results showed a good level of $0.68-0.90$. Our results were similar to those of previous studies. 
Figure 1 Confirmatory factor analyses for SF-36 scale

\begin{tabular}{|c|c|c|}
\hline e2 & $\longrightarrow$ & sf11 \\
\hline e3 & 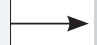 & sf10 \\
\hline e4 & & sf9 \\
\hline e6 & $\rightarrow$ & sf7 \\
\hline e7 & & sf6 \\
\hline e8 & $\rightarrow$ & sf5 \\
\hline e9 & & sf4 \\
\hline e10 & & sf3 \\
\hline
\end{tabular}

.78
.87
.86
.75
.81
.83
.93
.84

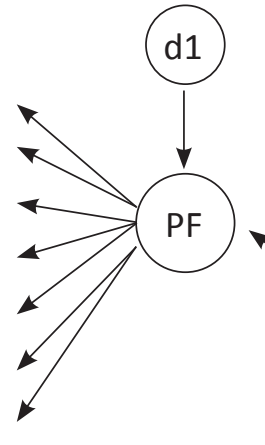

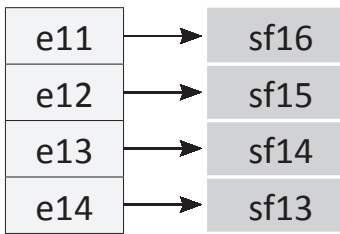

.90
.79
.90
.93

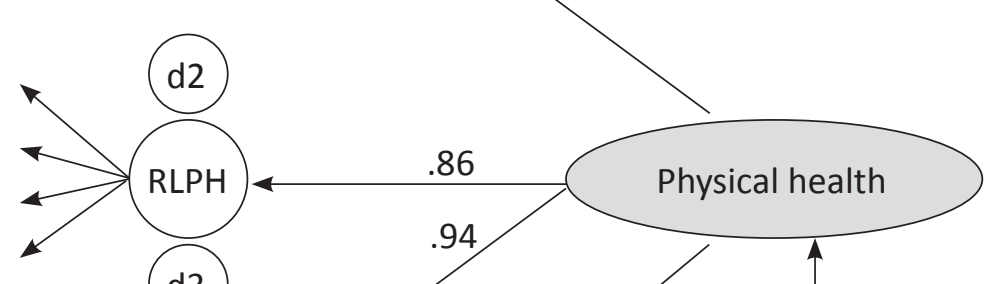

\begin{tabular}{|l|l|l|}
\hline $\mathrm{e} 15$ & $\longrightarrow$ & $\mathrm{sf36}$ \\
$\mathrm{e} 16$ & $\longrightarrow$ & $\mathrm{sf34}$ \\
$\mathrm{e} 17$ & $\longrightarrow$ & $\mathrm{sf33}$ \\
\end{tabular}

.88
.90
.83

\begin{tabular}{|c|c|}
\hline e18 & $\longrightarrow$ \\
\hline e19 & $\longrightarrow$ \\
\hline
\end{tabular}

.86

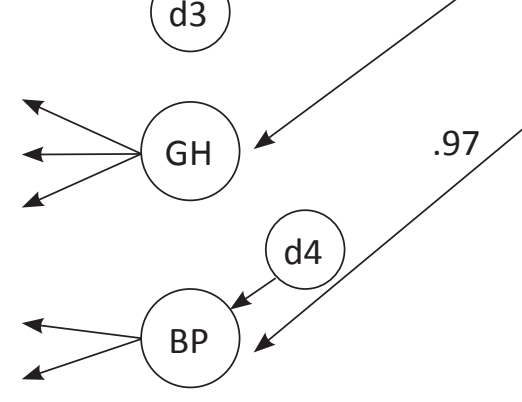

.87

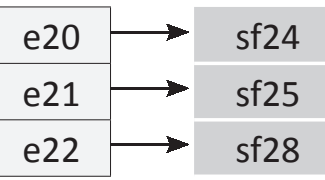

94
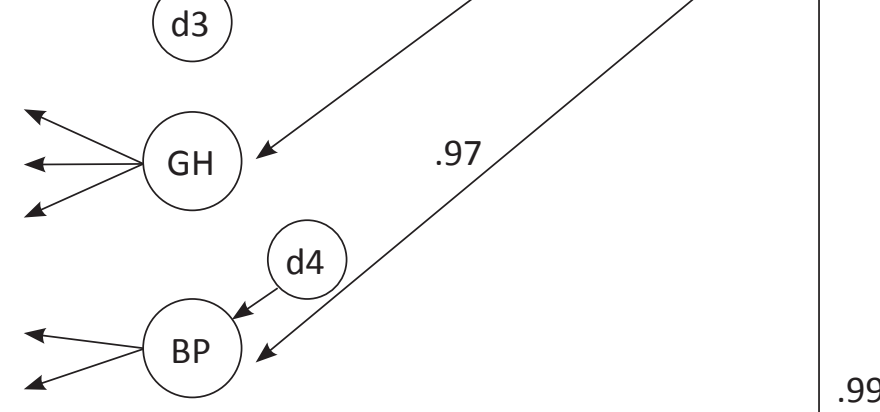

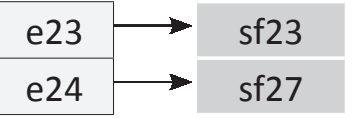

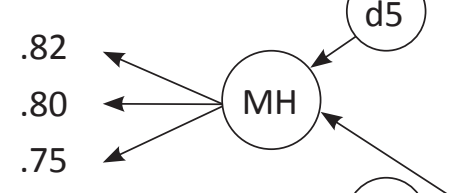

d5

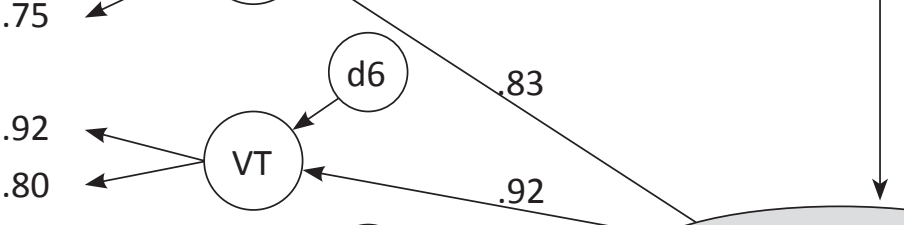

\begin{tabular}{|l|l|l|}
\hline $\mathrm{e} 25$ & $\longrightarrow$ & $\mathrm{sf17}$ \\
\hline $\mathrm{e} 26$ & $\longrightarrow$ & $\mathrm{sf1} 18$ \\
\cline { 1 - 1 } 227 & $\longrightarrow$ & $\mathrm{sf19}$ \\
\hline
\end{tabular}
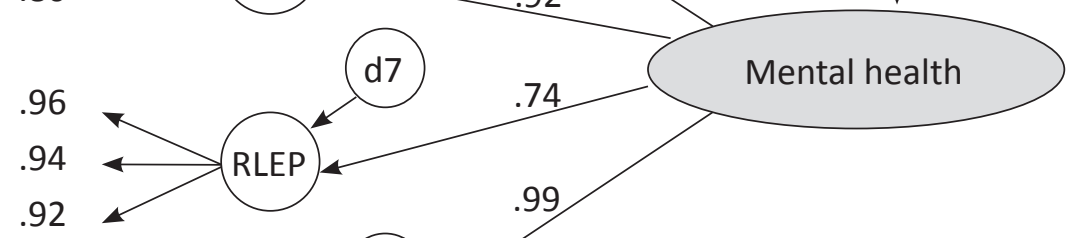

\begin{tabular}{|c|c|}
\hline e28 & $\longrightarrow$ \\
\hline e29 & $\longrightarrow$ \\
\hline
\end{tabular}

.88

.72

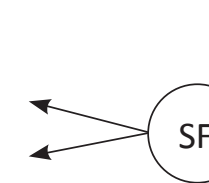

PF: Physical functioning, RLPH: Role limitation due to physical health, GH: General health perception, BP: Bodily pain, MH: Perceived mental health, VT: Vitality, RLEP: Role limitation due to emotional problems, SF: Social functioning

ei: Measurement error of observed variable

Arrows $(\leftarrow)$ : Standardized regression weights

Arrow $(\leftrightarrow)$ : Covariance between physical and mental health

Emotional well-being should be under the mental health dimension of SF, but it was correlated with the physical dimension in our study. However, the other subscales generally fitted into the original hypothesized association. Li et al. showed that VT and RLEP were loaded to the physical health subscale instead of emotional scales in the explanatory factor analyses (23). Fukuhara et al. (22) found that VT and RLEP were obtained under the physical health dimension and Montazari et al. (21) also found VT under physical health. Thumboo 


\begin{tabular}{|c|c|c|c|c|c|c|c|c|c|c|}
\hline Scale & $\begin{array}{l}\text { Correlation of } \\
\text { between test and } \\
\text { retest }(n=259)\end{array}$ & PF & RLPH & RLEP & VT & MH & SF & BP & GH & Cronbach's $\alpha$ \\
\hline $\mathrm{PF}$ & $0.905^{*}$ & 1.0 & & & & & & & & 0.933 \\
\hline RLPH & $0.714^{*}$ & $0.58^{*}$ & 1.0 & & & & & & & 0.849 \\
\hline RLEP & $0.682^{*}$ & $0.41^{*}$ & $0.55^{*}$ & 1.0 & & & & & & 0.854 \\
\hline VT & $0.815^{*}$ & $0.61^{*}$ & $0.51^{*}$ & $0.46^{*}$ & 1.0 & & & & & 0.758 \\
\hline $\mathrm{MH}$ & $0.783^{*}$ & $0.48^{*}$ & $0.38^{*}$ & $0.44^{*}$ & $0.61^{*}$ & 1.0 & & & & 0.767 \\
\hline SF & $0.753^{*}$ & $0.51^{*}$ & $0.51^{*}$ & $0.48^{*}$ & $0.57^{*}$ & $0.50^{*}$ & 1.0 & & & 0.753 \\
\hline $\mathrm{BP}$ & $0.762^{*}$ & $0.58^{*}$ & $0.58^{*}$ & $0.45^{*}$ & $0.55^{*}$ & $0.46^{*}$ & $0.78^{*}$ & 1.0 & & 0.864 \\
\hline GH & $0.864^{*}$ & $0.59^{*}$ & $0.52^{*}$ & $0.43^{*}$ & $0.66^{*}$ & $0.56^{*}$ & $0.65^{*}$ & $0.66^{*}$ & 1.0 & 0.871 \\
\hline
\end{tabular}

Dropped items: 1, 2, 8, 12, 26, 29, 30, 31 and 35 .

${ }^{*} \mathrm{P}<0.001$.

$\mathrm{BP}=$ bodily pain; $\mathrm{GH}$ = general health; $\mathrm{MH}=$ perceived mental health; $\mathrm{PF}=$ physical functioning; $\mathrm{RLEP}=$ role limitation due to emotional problems; $\mathrm{RLPH}=$ role limitation due to physical health; $S F=$ social functioning; VT = vitality.

et al. studied English and Chinese versions of SF-36 in a multiethnic urban population in Singapore and found small differences between the 2 versions (24). This result supports the suggestion that emotional dimensions may be affected by the perception of people from different cultural backgrounds.

The strength of the study was that the provisional version of the questionnaire was provided after careful review and cultural adaptation. In general, there were no difficulties in translating response categories, except that bowling and playing golf were changed to light sporting activities, mile was been changed to kilometre, and walking or several blocks was changed to walking one or several alleys to refer to a similar distance in the Persian language. The provisional forward translated questionnaire was pilot tested and administered to a sample of 50 healthy individuals in all age groups within the inclusion criteria.-
The study had some limitations. The Persian version of SF-36 was administered to a random sample of healthy individuals aged $\geq 18$ years living in Herat City; therefore, this study only represented people living in Herat and speaking Dari, not for all regions in Afghanistan. SF-36 needs to be translated into Pashto and the other languages spoken in the country, and validity and reliability studies need to be conducted in different regions of the country. There is not any other QOL scale in Persian in the country; therefore, the validity test could not be conducted using direct statistical comparison, such as invariance analysis and differential item functioning. After developing new scales to measure QOL in Afghanistan, the validity test can be repeated to conduct comparisons in the different regions of the country.

In conclusion, the study has shown that SF-36 in Dari language is suitable to evaluate QOL of adults in Herat Province, Afghanistan.

Table 4 Correlations between 8 scales in SF-36 and rotated principal components

\begin{tabular}{lcccc} 
Scale & \multicolumn{2}{c}{ Hypothesised association } & Rotated principal components (Varimax) \\
& Physical & Mental & Physical & Mental \\
\hline Physical functioning & $*$ & $*$ & 0.647 & 0.364 \\
Role limitation due to physical health & $*$ & + & 0.416 & 0.717 \\
Role limitation due to emotional problems & - & - & 0.208 & 0.871 \\
Vitality & + & $*$ & 0.863 & 0.170 \\
Mental health & $*$ & $*$ & 0.733 & 0.335 \\
Social functioning & + & - & 0.740 & 0.358 \\
Bodily pain & + & - & 0.888 & 0.370 \\
General health & + & $*$ & 0.192 \\
\hline
\end{tabular}

+ strong association $(r \geq 0.70)$; ${ }^{*}$ moderate association $(0.30<r<0.70)$; - weak association $(r \leq 0.30)$.

Dropped items: 1, 2, 8,12, 26, 29, 30, 31 and 35 . 


\begin{tabular}{|c|c|c|c|c|c|c|}
\hline Author & Country & $\begin{array}{l}\text { Publication } \\
\text { year }\end{array}$ & Population & Cronbach's $\alpha$ & Other analysis & Refs \\
\hline Failde and Ramos & Spain & 2000 & $\begin{array}{l}185 \text { patients hospitalized } \\
\text { with suspected ischemic } \\
\text { cardiopathy }\end{array}$ & $0,72-0,94$ & & 11 \\
\hline Wagner et al. & Tanzania & 1999 & 3802 adults & $\begin{array}{l}\text { Overall } 0.81,0.70- \\
0.92\end{array}$ & & 14 \\
\hline Apolone and Mosconi & Italy & 1998 & 2031 adults & $0.77-0.93$ & $\begin{array}{l}\text { Test-retest } \\
\text { reliability }>0.70\end{array}$ & 15 \\
\hline $\begin{array}{l}\text { Frempong-Ainguah } \\
\text { and Hill }\end{array}$ & Ghana & 2014 & $\begin{array}{l}2814 \text { women, aged } \geq 20 \text { years } \\
\text { in urban Ghana }\end{array}$ & $\begin{array}{c}\text { Overall } 0.82,0.69- \\
0.94\end{array}$ & & 16 \\
\hline Jenkinson et al. & $\begin{array}{l}\text { United } \\
\text { Kingdom }\end{array}$ & 1999 & 8889 adults & $0.80-0.92$ & & 17 \\
\hline Scott et al. & New Zealand & 1999 & $\begin{array}{l}11921 \text { households and } 7862 \\
\text { adults, aged } \geq 15 \text { years }\end{array}$ & $0.78-0.93$ & & 18 \\
\hline Koçyigit et al. & Turkey & 1999 & $\begin{array}{l}50 \text { healthy individuals and } 50 \\
\text { patients with back pain }\end{array}$ & $0.7324-0.7612$ & & 19 \\
\hline Zhang Y et al. & China & 2012 & $\begin{array}{l}1358 \text { 3rd and } 4 \text { th medical } \\
\text { school students }\end{array}$ & $\begin{array}{l}\text { Overall } 0.791 \\
\text { Social functions } \\
\quad(0.631)\end{array}$ & $\begin{array}{l}\text { Test-retest } \\
\text { reliability } \\
0.59-0.86\end{array}$ & 20 \\
\hline Montazeri et al. & Iran & 2005 & $\begin{array}{l}4163 \text { healthy individuals, aged } \\
\geq 15 \text { years }\end{array}$ & $\begin{array}{l}\text { 0.77-0.90 except } \\
\text { VT (0.65) }\end{array}$ & $\begin{array}{l}\text { Convergent } \\
\text { validity } \\
0.58-0.95\end{array}$ & 21 \\
\hline Fukuhara et al. & Japan & 1998 & 588 adults & $0.71-0.86$ & $\begin{array}{l}\text { Test-retest } \\
0.78-0.93\end{array}$ & 22 \\
\hline Li et al. & China & 2003 & $\begin{array}{l}1000 \text { households in } 18 \\
\text { communities }\end{array}$ & $\begin{array}{c}\text { 0.72-0.88 except SF } \\
\text { (0.39) and VT scale } \\
(0.39)\end{array}$ & $\begin{array}{c}\text { Test-retest } \\
\text { reliability } \\
\text { coefficients } 0.66- \\
0.94\end{array}$ & 23 \\
\hline Thumboo et al. & Singapore & 2013 & $\begin{array}{c}4917 \text { participants } \\
\text { Aged } \geq 21 \text { years } \\
4115 \text { participants for English } \\
\text { version } \\
802 \text { participants for Chinese } \\
\text { version }\end{array}$ & $\begin{array}{l}\text { Exceeded } 0.70 \text { for } \\
\text { all English and } \\
\text { Chinese versions } \\
\text { (except social } \\
\text { functioning ( } 0.68 \text { ) } \\
\text { in Chinese version }\end{array}$ & & 24 \\
\hline Sabbah et al. & Lebanon & 2000 & $\begin{array}{c}347 \text { households, aged } 14-86 \\
\text { years }\end{array}$ & Exceeded 0.70 & $\begin{array}{l}\text { Comparable to the } \\
\text { scales in the USA } \\
\text { and France }\end{array}$ & 25 \\
\hline
\end{tabular}

\section{Acknowledgement}

We would like to acknowledge Ms J. Fayzi, for coordinating data collection in the field.

Funding: None.

Competing interests: None declared. 


\section{Enquête de santé abrégée (SF-36) : traduction et étude de validation en Afghanistan \\ Résumé}

Contexte : La qualité de vie est définie comme la perception subjective du propre bien-être d'une personne dans un contexte socioculturel. Le questionnaire SF-36 (Enquête de santé abrégée) est couramment utilisé pour vérifier l'état de santé de la population générale dans de nombreux pays

Objectifs : Valider la version en langue persane (dari) du SF-36 à Herat.

Méthodes: La version en langue persane (dari) du SF-36 a été adaptée en tenant compte de la culture. Au total, 1259 personnes en bonne santé âgées de 18 ans ou plus ont participé à l'étude entre novembre 2016 et avril 2017. La validité structurelle du SF-36 a été évaluée à l'aide de l'analyse factorielle exploratoire. L'extraction a été effectuée par analyse en composantes principales à partir de la matrice de corrélation polychorique estimée par une méthode en deux étapes avec rotation varimax. La cohérence interne et la fidélité test-retest ont été évaluées par la méthode de l'alpha de Cronbach. Les logiciels SPSS (version 23.0) et $\mathrm{R}$ (version 3.1.3) ont été utilisés pour l'analyse.

Résultats : La dernière version du SF-36 comprenant 27 items assortis à huit facteurs expliquait 86,48 \% des variations. La valeur de Kaiser-Meyer-Olkin était de 0,391 et le test de Bartlett a montré une signification statistique ( $p<0,001)$. L'analyse factorielle confirmatoire a révélé que le modèle final présentait de bonnes statistiques d'ajustement $(p<0,001)$, une erreur quadratique moyenne d'approximation de 0,056, un indice de qualité de l'ajustement de 0,963 et un indice ajusté de la qualité de l'ajustement de 0,953. Le coefficient alpha de Cronbach pour les huit sous-échelles était de 0,7530,933. Toutes les sous-échelles du SF-36 présentaient une bonne fidélité de cohérence interne et une bonne fidélité testretest.

Conclusions : Nous avons démontré que notre version en langue dari du SF-36 est adaptée pour évaluer la qualité de vie des adultes dans la ville de Herat. Cette échelle sera utile aux chercheurs en santé à l'avenir.

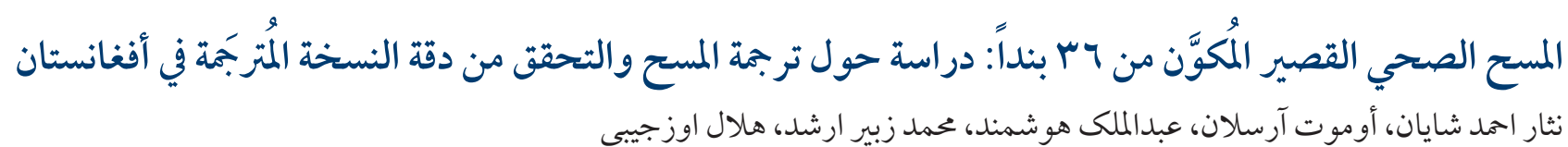

الخلفية: إن قياس جودة الحياة مهم لتقييم احتياجات الرعاية الصحية وتأثير الخدمات الصحية. هناك حاجة لقياس جودة الحياة في أفغانستان. الأهداف: هدفت هذه الدر اسة إلى التحقق من دقة النسخة الفارسية (لغة الداري) من المسح الصحي القصير المُكوَّن من 36 بنداً في مدينة هيرات.

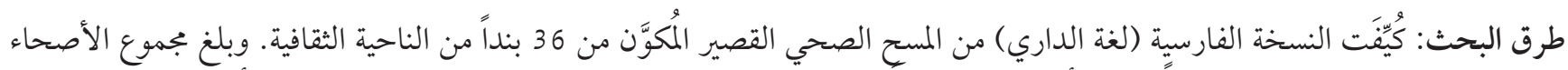

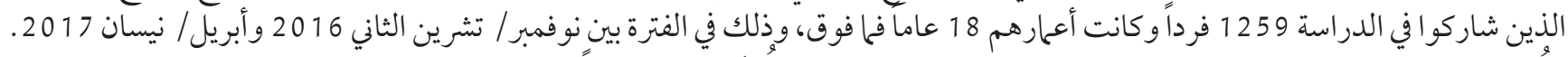

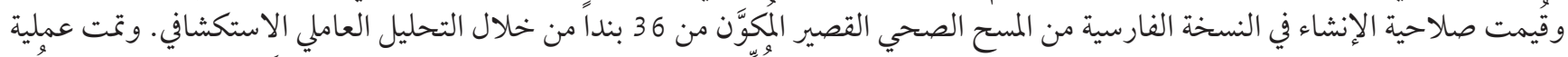

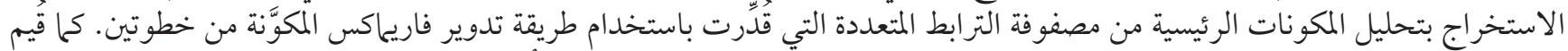

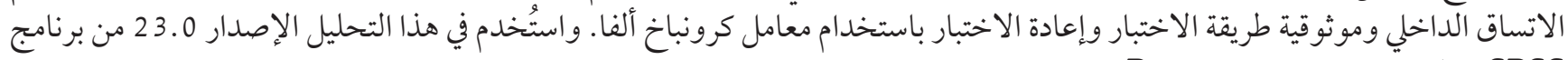
R و والإصدار SPSS

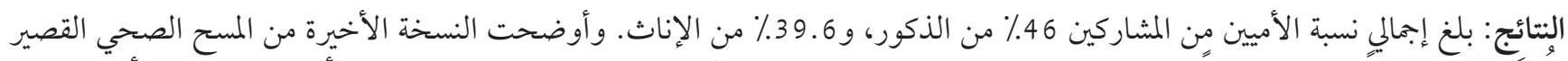

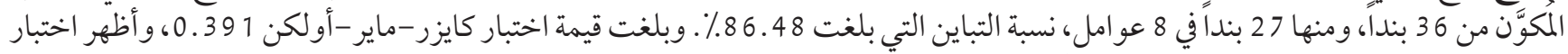

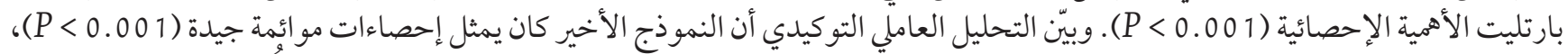

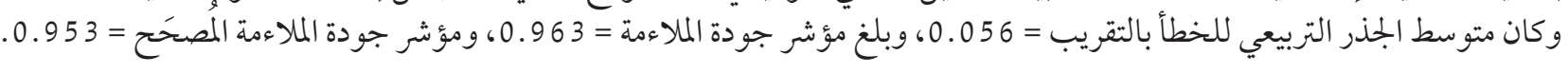

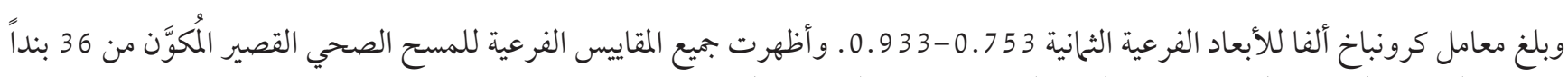

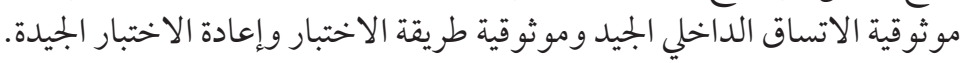

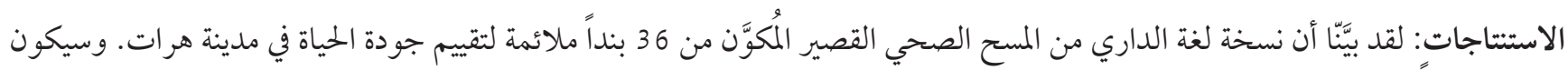

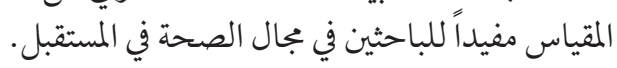




\section{References}

1. Ware JE Jr, Sherbourne CD. The MOS 36-item short-form health survey (SF-36). I. Conceptual framework and item selection. Med Care. 1992 Jun;30(6):473-83. PMID:1593914

2. Brazier J. The SF-36 health survey questionnaire - a tool for economists. Health Econ. 1993 Oct;2(3):213-5. http://dx.doi. org/10.1002/hec.4730020304 PMID:8275166

3. Wassertheil-Smoller S, Smoller J. Mostly about quality of life. In: Biostatistics and epidemiology. New York: Springer; 2015:16370. https://link.springer.com/chapter/10.1007/978-1-4939-2134-8_7

4. Lallukka T, Sivertsen B, Kronholm E, Bin YS, Øverland S, Glozier N. Association of sleep duration and sleep quality with the physical, social, and emotional functioning among Australian adults. Sleep Health. 2018 Apr;4(2):194-20o. http://dx.doi. org/10.1016/j.sleh.2017.11.006 PMID:29555134

5. Lahmek P, Berlin I, Michel L, Berghout C, Meunier N, Aubin HJ. Determinants of improvement in quality of life of alcohol-dependent patients during an inpatient withdrawal program. Int J Med Sci. 2009 May 18;6(4):160-7. http://dx.doi.org/10.7150/ ijms.6.160 PMID:19461935

6. Corcoran WE, Durham CF. Quality of life as an outcome-based evaluation of coronary artery bypass graft critical paths using the SF-36. Qual Manag Health Care. 2000 Winter;8(2):72-81. http://dx.doi.org/10.1097/00019514-200008020-00008 PMID:10787509

7. Sugawara N, Sato K, Takahashi I, Satake R, Fukuda S, Nakaji S et al. Irritable bowel syndrome and quality of life in a community-dwelling population in Japan. Int J Psychiatry Med. 2018 May;53(3):159-70. http://dx.doi.org/10.1177/0091217417749791 PMID:29280689

8. Razavi D, Gandek B. Testing Dutch and French translation of the SF-36 Health Survey among Belgian angina patients. J Clin Epidemiol. 1998 Nov;51(11):975-81. http://dx.doi.org/10.1016/s0895-4356(98)0oo89-4 PMID:9817115

9. Koohi F, Nedjat S, Yaseri M, Cheraghi Z. Quality of life among general populations of different countries in the past 10 Years, with a focus on human development index: A systematic review and meta-analysis. Iran J Public Health. 2017 Jan;46(1):12-22. PMID:28451525

10. Mavaddat N, Kinmonth AL, Sanderson S, Surtees P, Bingham S, Khaw KT. What determines Self-Rated Health (SRH)? A cross-sectional study of SF-36 health domains in the EPIC-Norfolk cohort. J Epidemiol Community Health. 2011 Sep;65(9):800-6. http://dx.doi.org/10.1136/jech.2009.090 PMID:20551149

11. Failde I, Ramos I. Validity and reliability of the SF-36 Health Survey Questionnaire in patients with coronary artery disease. J Clin Epidemiol. 2000 Apr;53(4):359-65. http://dx.doi.org/10.1016/s0895-4356(99)00175-4 PMID:10785566

12. Lins L, Caevalho FM. SF-36 total score as a single measure of health-related quality of life: Scoping review. SAGE Open Med. 2016 Oct 4;4:1-12. http://dx.doi.org/10.1177/2050312116671725 PMID:27757230

13. Doosti-Irani A, Nedjat S, Nedjat S, Cheraghi P, Cheraghi Z. Quality of life in Iranian elderly population using the SF-36 questionnaire: systematic review and meta-analysis. East Mediterr Health J. 2018 Jan 23;24(11):1088-97. http://dx.doi. org/10.26719/2018.24.11.1088 PMID:30701524

14. Wagner AK, Wyss K, Gandek B, Kilima PM, Lorenz S, Whiting D. A Kiswahili version of the SF-36 Health Survey for use in Tanzania: Translation and test of scaling assumptions. Qual Life Res. 1999; 8(1-2):101-10. http://dx.doi.org/10.1023/a:1026441415079 PMID:10457743

15. Apolone G, Mosconi P. The Italian SF-36 Health Survey: translation, validation and norming. J Clin Epidemiol. 1998 Nov;51(11):1025-36. http://dx.doi.org/10.1016/s0895-4356(98)0oo94-8 PMID:9817120

16. Frempong Ainguah A, Hill A. Reliability, validity and responsiveness of the short form-36 health survey: findings from the women's health study of Accra, Ghana. Quetelet J. 2014;2:7-29.

17. Jenkinson C, Stewart-Brown S, Petersen S, Paice C. Assessment of the SF-36 version 2 in the United Kingdom. J Epidemiol Community Health. 1999 Jan;53(1):46-50. http://dx.doi.org/10.1136/jech.53.1.46 PMID:10326053

18. Scott KM, Tobias MI, Sarfati D, Haslett SJ. SF-36 health survey reliability, validity and norms for New Zealand. Aust N Z J Public Health. 1999 Aug;23(4):401-6. http://dx.doi.org/10.1111/j.1467-842X.1999.tbo1282.x PMID:10462864

19. Koçyiğit H, Aydemir O, Fişek G, Ölmez N, Memiş A. [Reliability and validity of the Turkish Version of Short Form-36 (SF-36)]. İlaç ve Tedavi Dergisi 1999 Jan 1;12:102-6 (in Turkish).

20. Zhang Y, Qu B, Lun S, Guo Y, Liu J. The 36-item short form health survey: reliability and validity of Chinese medical students. Int J Med Sci. 2012;9(7):521-6. http://dx.doi.org/10.7150/ijms.4503 PMID:22991490

21. Montazeri A, Goshtasebi A, Vahdniani M, Gandek B. The short from health survey (SF-36): translation and validation study of Iranian version. Qual Life Res. 2005 Apr;14(3):875-82. http://dx.doi.org/10.1007/s11136-004-1014-5 PMID:16022079

22. Fukuhara S, Bito S, Green J, Hsiao A, Kurokawa K. Translation, adaptation, and validation of the SF-36 Health Survey for use in Japan. J Clin Epidemiol. 1998 Nov;51(11):1037-44. http://dx.doi.org/10.1016/s0895-4356(98)00095-x PMID:9817121

23. Li L, Wang HM, Shen Y. Chinese SF-36 Health Survey: Translation, cultural adaptation, validation, and normalization. J Epidemiol Community Health. 2003 Apr;57(4):259-63. http://dx.doi.og/10.1136/jech.57.4.259 PMID:12646540

24. Tuhumboo J, Wu Y, Tai ES, Gandek B, Lee J, Ma S, et al. Reliability and validity of the English (Singapore) and Chinese (Singapore) versions of the Short-Form 36 version 2 in a multi-ethnic Urban Asian population in Singapore. Qual Life Res. 2013 Nov;22(9):2501-8. http://dx.doi.org/10.1007/s11136-013-0381-1 PMID:23475690 
25. Sabbah I, Drouby N, Sabbah S, Retel-Rude N, Mercier M. Quality of life in rural and urban populations in Lebanon using SF-36 Health Survey. Health Qual Life Outcomes. 2003 Aug 6;1:30. http://dx.doi.org/10.1186/1477-7525-1-30 PMID:12952543

26. Basto M, Pereira JM. An SPSS R-menu for ordinal factor analysis. J Statistical Software. 2012;46(4):1-30. http://dx.doi. org/10.18637/jss.v046.io4

27. Cronbach LJ. Coefficient alpha and the internal structure of tests. Psychometrika 1951;16:297-334.

28. Nunnally JC. Psychometric theory. New York: McGraw-Hill; 1987. 